\title{
Seven Diverse Phaseolus Germplasm Lines Derived through Interspecific Hybridization of Common Bean and Tepary Bean
}

\author{
Richard C. Pratt ${ }^{1}$ and Joseph C. Scheerens \\ Department of Horticulture and Crop Science, Ohio Agricultural Research \\ and Development Center, The Ohio State University, Wooster OH 44691
}

\section{Soon J. Park \\ Agriculture and Agri-Food Canada, Greenhouse and Processing Crops Centre, 2585 County Road 20, Harrow, Ontario NOR 1G0}

Additional index words. backcross, breeding, common bacterial blight, host-resistance, genetic diversity, gene pool, germplasm enhancement, introgression, Xanthomonas

The Ohio Agricultural Research and Development Center announces the release of seven diverse Ohio Phaseolus germplasm (OPG) lines developed through interspecific hybridization between distinct common bean (P. vulgaris L.) parents and a subspecies cross between cultivated (P. acutifolius A. Gray var. latifolius Freeman) and wild (P. acutifolius var. tenuifolius A. Gray) tepary bean. The backcross lines were selected from populations that arose from crosses between a self-sterile interspecific hybrid and both small- and large-seeded recurrent common bean parents.

The tepary bean is a traditional crop produced primarily in semi-arid regions of the southwestern U.S. and northern Mexico (Pratt and Nabhan, 1988). It is a potential germplasm donor of highly desirable traits for improvement of common bean (Pratt, 1983; Pratt and Nabhan, 1985; Singh, 2001; Thomaset al., 1983). Tepary bean displays resistance to multiple pathogens and pests causing serious economic damage to common bean, as well as drought, salinity and heat stress tolerance (Singh, 2001). Deleterious traits in tepary bean that may pose drawbacks to successful integration of desirable traits include susceptibility to bean common mosaic virus (BCMV) (Pratt and Nabhan, 1985) and to white mold [causal agent Sclerotinia sclerotiorum (Lib.) de Bary] (personal observation). Tepary beans

Received for publication 27 July 2005 . Accepted for publication 25 Sept. 2005. We are especially grateful to James D. Kelly (Michigan State University) for his ongoing support and advice throughout the project and for examining the lines in Michigan in 2003. We thank David Willmott, David Francis, and Steve St. Martin for reviewing earlier drafts of the manuscript. Mark Casey and Terry McGriff provided valuable technical assistance and Monica Bongue of Muddy Fork Farm kindly provided plot space in 2000. Manuscript no. HCS05-27, Ohio Agricultural Research and Development Center. The mention of firm names or trade products does not imply that they are endorsed or recommended by The Ohio State University over other firms or similar products not mentioned.

${ }^{1}$ To whom reprint requests should be sent; e-mail pratt.3@osu.edu. do not germinate well during cold weather (Thomas et al., 1983) may contain unusually high levels of lectins, and sometimes require prolonged cooking times (Kabbara et al., 1987). Indeterminacy, short-day photoperiodicity of Central American accessions (Pratt and Erickson, 1989), seed size smaller than most small-seeded varieties of common bean, and a slight tendency of pods to shatter prematurely (Pratt and Nabhan, 1985) may also present additional problems in selection of elite cultivars for particular environments or markets.

Pronounced reproductive barriers separate common and tepary beans, and embryo rescue is necessary to obtain interspecific hybrids (Sabja et al., 1990; Waines et al., 1988). The successful recovery of backcrosses from sterile hybrids also presents major challenges and different avenues for recovery of fertile backcrosses have been explored (Mejía-Jimenez et al., 1994; Pratt and Gordon, 1994; Thomas and Waines, 1984; Waines et al., 1988). Gene introgression into backcross populations using common bean as the recurrent parent has been studied by Pratt and Gordon (1994) and through congruity backcrossing by Mejia-Jimenez et al. (1994). Common bacterial blight [causal agent Xanthomonas campestris pv. phaseoli (Smith) Dye $=X$. axonopodis pv. phaseoli (Smith)Vauterin et al.] resistance has been transferred from tepary to common bean (Scott and Michaels, 1992; Singh, 2001) but the transfer of more complex traits has not been reported.

The possibility of linkage drag caused by deleterious donor genes or chromosomal segments, or differential transmission of P. vulgaris alleles, are potential barriers to successful introgression of useful genes from related species, such as tepary bean, in the tertiary gene pool of common bean. Use of tepary bean germplasm resources might be increased if it could be demonstrated that desirable lines could be obtained from interspecific backcross populations. Instead of introgressing a single desirable trait from tepary bean into common bean, we wished to determine if it would be possible to select $\mathrm{BC}_{2}$ and $\mathrm{BC}_{3}$ populations (common bean recurrent parent) with high yield potential. An additional objective was to determine iflinkages to negative traits associated with tepary bean would hinder successful selection. It is hoped that the findings and the germplasm resulting from this project will contribute to the long-term improvement and broadening of the gene-base of common bean.

\section{Origin}

Interspecific hybridization between diverse common bean genotypes and tepary bean was performed as described in Pratt et al. (1985). Backcrosses between self-sterile interspecific hybrids and $P$. vulgaris recurrent parents were undertaken as described by Pratt et al. (1985) and Pratt and Gordon (1994). The backcross lines arose from the interspecific hybrid designated $\mathrm{F}_{1}-3$. It was a result of a cross between a $P$. vulgaris hybrid ('Sanilac'/Puebla152Bl) and an individual $F_{2}$ plant obtained from the cross between a cultivated and a wild tepary accession (PI 440790/MBAC). Additional backcrosses were made to diverse $P$. vulgaris parents (Pratt and Gordon, 1994; Pratt et al., 1985). Fifty seed, or as many as available, from eight $\mathrm{S}_{0} \mathrm{BC}_{2}$ and one $\mathrm{S}_{0} \mathrm{BC}_{3}\left(\mathrm{~S}_{0}=\mathrm{F}_{2}\right)$ populations were planted in the greenhouse and selected for fertility (production of at least 10 mature seed per plant). In 1992, about $300 \mathrm{~S}_{0: 1}$ progenies obtained from eight $\mathrm{BC}_{2}$ populations, and one $\mathrm{BC}_{3}$ population, were space-planted in singlerow plots at the Ohio Agricultural Research and Development Center(OARDC) near Wooster. Selections were made in unreplicated nurseries within and across lines using the pedigree method through the $\mathrm{S}_{3} \mathrm{BC}_{2}$ and $\mathrm{BC}_{3}$ generations. Selections were based on acceptable maturity, upright or short vine habit, and production of pods and seeds that remained sound until a delayed harvest was conducted in late October or early November. Replicated performance evaluations of 20 selected lines were initiated in 1995. Further selection of lines was conducted based on yield and the criteria mentioned previously. Bulked seed from selected lines were sorted based on seed characteristics and several color variant sister lines of $\mathrm{S}_{4} \mathrm{BC}_{2}$ and $\mathrm{BC}_{3}$ lines were formed. Additional replicated performance evaluations and selections were conducted at one site in 1997 and at two sites in 2000. All tests conducted through 2000 were performed in Wayne County, Ohio in bordered plots with 76-cm row spacing except the 2000 test at Muddy Fork Farm which was planted in unbordered two-row plots with $30-\mathrm{cm}$ row spacing. A random complete block experimental design was used in all replicated field evaluations. Selected $\mathrm{S}_{6} \mathrm{BC}_{2}$ andBC $\mathrm{C}_{3}$ lines were increased in the greenhouse in 2001.

In 2002 and 2003 evaluations of the responses to infection by $X$. campestris pv. phaseoli, causal agent of common bacterial blight, and agronomic characteristics, of the advanced $\mathrm{BC}$ lines were determined in Ontario, Canada. Four local strains, two of isolates $X$. campestris pv. phaseoli fuscans no. 12 and no. 118, and two of nonfuscans no. 18 and no. 98 , were grown on yeast salts-agar (Dye 1968) for $48 \mathrm{~h}$ at $25^{\circ} \mathrm{C}$. A sterile distilled water suspension of bacterial 


\begin{tabular}{lcc}
\hline Accession & Origin & Market class \\
\hline P. vulgaris & & \\
GO-4115 & C.I.A.T. accession & Black (small seed) \\
'Jamapa' & Mexico (Costa Rican accession) & Black (small seed) \\
'Masterpiece' & United Kingdom & Fresh market \\
'Pinquito' & U.S. (Calif.) & Brown specialty \\
Puebla 152B1 & Mexico & Black (large sd.) \\
'Sanilac' & U.S. (MI) & White Navy \\
UI-114 & U.S. (Idaho) & Pinto \\
P. acutifolius & &
\end{tabular}

P. acutifolius PI 440790

Mexico (Sonora)

White (cultivated)

P. acut. var. acutifolius MBAC

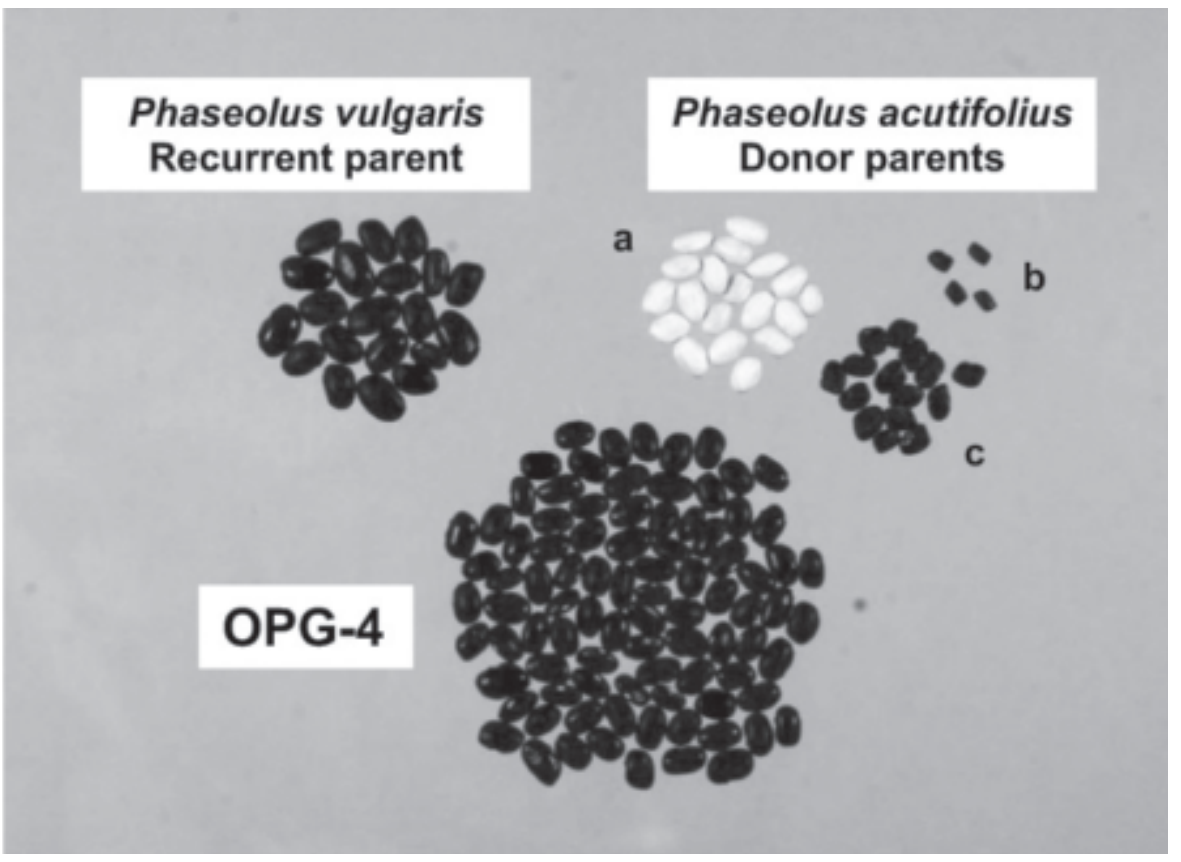

Fig. 1. Seed samples of the BC3 line OPG-4 derived from interspecific hybridization of Phaseolus vulgaris and a $P$. acutifolius subspecies cross. Also shown in the upper portion of the figure are the last $P$. vulgaris recurrent parent ('Jamapa'), the $P$. acutifolius donor parents (a) PI 440790 (cultivated) and (b) MBAC (wild), and (c) F2:3 seed obtained by selfpollination of the plant (F2-K2A) used as the parent in the original interspecific cross.

growth was made, adjusting concentration to 15 Klett units against a red filter in a Klett-Summerson colorimeter. Suspensions of the four strains were mixed in equal volume and $7 \mathrm{~L}$ were added to $190 \mathrm{~L}$ of water in a spray tank. The inoculum, containing $10^{6}$ colony forming units $/ \mathrm{mL}$, was applied to 3 -week-old plants at about $1333 \mathrm{kPa}$ to ensure visible water-soaking injury using a spray boom. Disease severity assessments were made 3 and 6 weeks after inoculation of unreplicated single-row field plots. In 2003, agronomic characteristics of the advanced BC lines also were determined in an unreplicated field plot in Michigan through the courtesy of James Kelly.

Following the evaluations conducted over several years, seven advanced lines were selected for release. The selected lines OPG1 and OPG-2 were selected from the $\mathrm{BC}_{2}$ population (2-4), which had CIAT Go4115 as the first recurrent parent and 'Jamapa' as the second recurrent parent. The other five backcross lines were selected from the $\mathrm{BC}_{3}$ population (1-2-1), which had Pinquito/Pinto
UI-114)//'Masterpiece' as the first recurrent parent; 'Sanilac'/Puebla152B1 as the second recurrent parent; and 'Jamapa' as the third recurrent parent) (Table 1) (Figs. 1, 2, and 3).

\section{Description and Performance}

The yield of all released OPG lines was not significantly different $(P=0.05)$ from check cultivar 'Jamapa' in a combined ANOVA (Table. 2). Most lines displayed average lodging resistance and again no significant differences were detected between the parental check 'Jamapa' and any of the germplasm lines (Table 2 ). The lines displayed considerable variation in architecture, from upright bush (Type I) to prostrate vine (Type III) and this variation also was observed within some lines (Table 2). The lines also displayed varying degrees of indeterminacy, and some variation was observed for vine length among the indeterminate types (Type II), so this group was split into a and b subclassifications that were semi-determinate and indeterminate vining, respectively (Table 


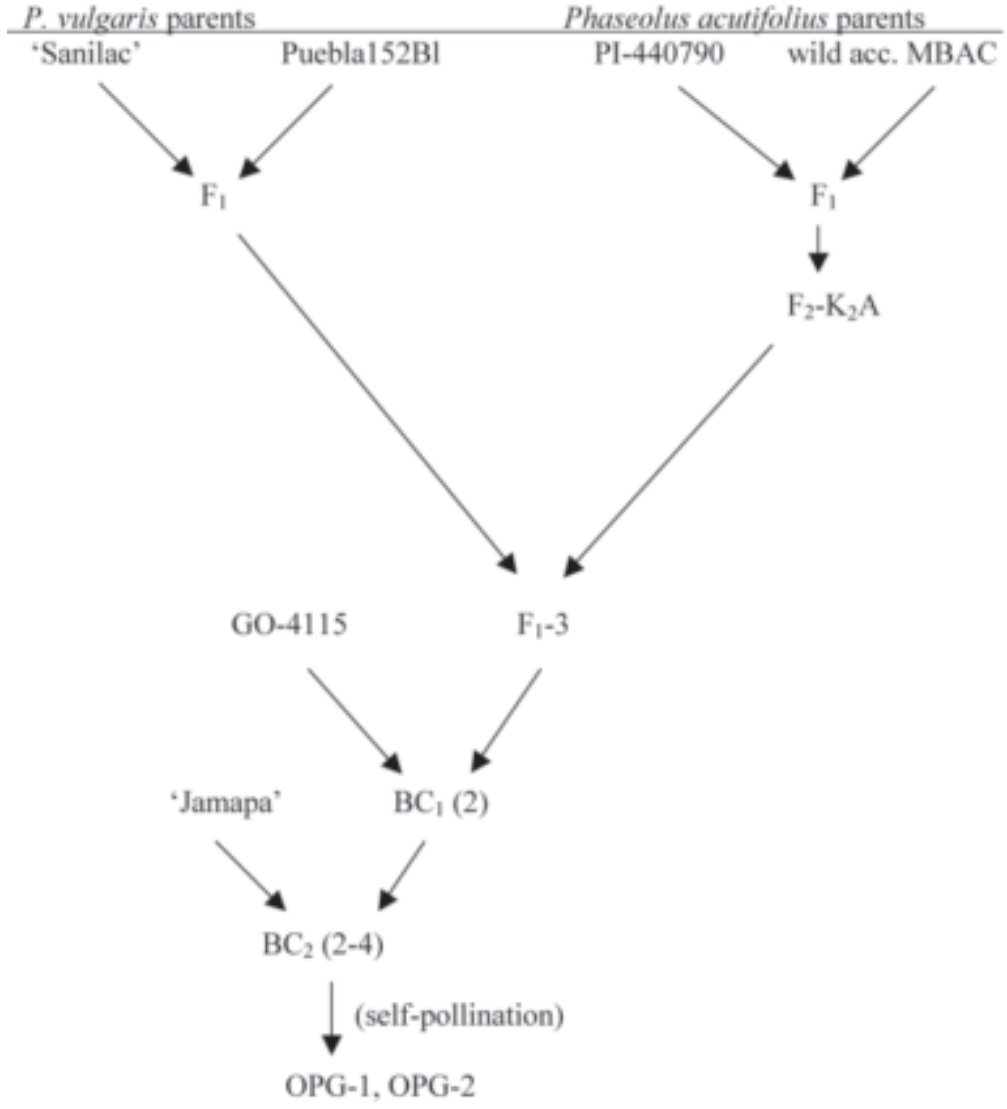

Fig. 2. Pedigree of Phaseolus germplasm lines OPG-1and 2.

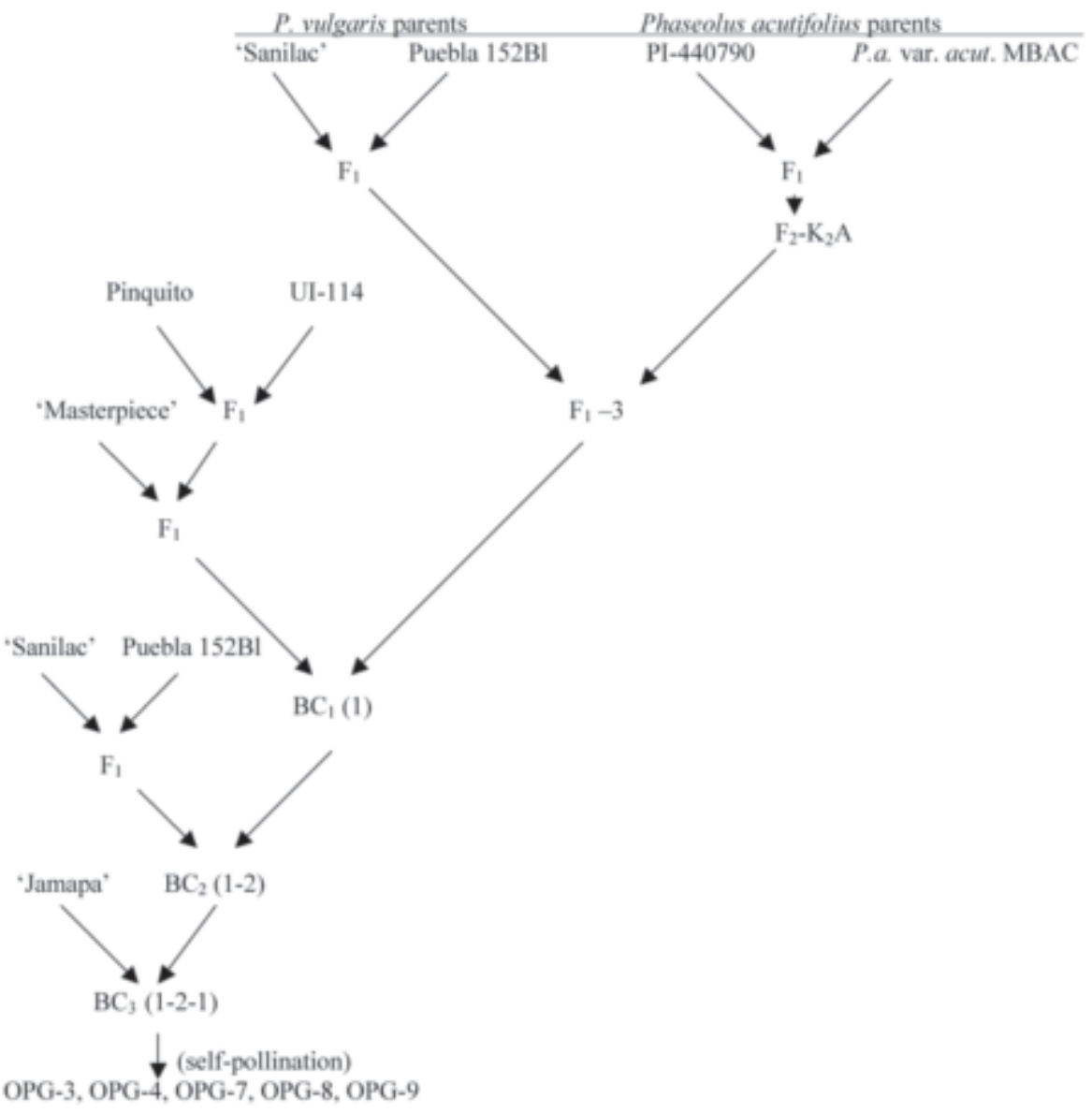

Fig. 3. Pedigree of Phaseolus germplasm lines OPG-3,4 and OPG-7,8, and 9.
2 ). The maturity of some lines (OPG 2, 7, and 9) is suitable for the Great Lakes region whereas others are too late-maturing and may be better suited elsewhere (Table 2).

The seed colors and patterns displayed by the lines are highly diverse - ranging from white, light to dark brown, pinto-like variegation, pink and red, to black and mottled. (Table 2 ). Seed coat color variation is apparent in some of the lines (especially OPG-3) because it has not been possible to fix the predominant color type. Most seed weights are comparable to those of the small-seeded to medium weight common beans (Table 3 ). Water imbibition and cookability of seeds stored at room temperature for one year was determined according to the methods of Jackson and Varianno-Marston (1981). All lines displayed water imbibition and cookability properties similar to those of 'Jamapa' and commercially available checks, with the exception of OPG-1, which was somewhat slower to imbibe water.

It has been confirmed that the tepary bean parents used in this study demonstrated highly resistant/immune responses when screened using a mixture of several $X$. campestris pv. phaseoli isolates from southern Ontario. Evaluations conducted in Ontario during two seasons using several local isolates revealed that some of the lines display resistance to infection by $X$. campestris pv. phaseoli, but that resistance is segregating within lines (Table 2). Susceptible plants were present in the partially inbred line obtained from the $\mathrm{F}_{2}$ tepary parent used to produce the interspecific hybrids, suggesting PI 440790 and MBAC were not allelic for $\mathrm{CBB}$ resistance. Both segregation within accessions and multiple alleles for resistance in tepary bean has been previously demonstrated by Urrea et al. (1999). Directed selection for resistance in the lines may provide additional genes for pyramiding resistance in commercial common bean cultivars (Singh, 2001).

The lines were planted for seed increase and purification in 2001. Seed harvested from these plots were grown in the greenhouse during the winter of 2001-02 to confirm plant health and produce seed in a disease free environment.

\section{Availability}

Samples of seed may be obtained for a fee from Richard C. Pratt, Department of Horticulture and Crop Science, OSU/OARDC, 1680 Madison Ave. Wooster, OH 44691. One sample will be provided without charge to non-profit breeders and researchers. A material transfer agreement (MTA) will provide guidelines for use of the germplasm.

\section{Literature Cited}

Dye, D.W. 1968. A taxonomic study of the genus Erwinia. 1. The amylovora group. N.Z. J. Sci. 11:590-607.

Jackson, G.M. and E. Varianno-Marston. 1981. Hard-to-cook phenomenon in beans: Effects of accelerated storage on water absorption and cooking time. J. Food Sci. 46:799-803.

Kabbara, S.A.R. I.R. Abbas, J.C. Scheerens, A.M. Tinsley, and J.W. Berry. 1987. Soaking and cooking parameters of tepary beans: effects of 
Table 2. Yield and agronomic characteristics of seven dry bean germplasm lines and a varietal check cultivar grown over 5 locations in Ohio (1995-2000), two seasons in Ontario, Canada (2002-2003) and during one season in Michigan (2003).

\begin{tabular}{|c|c|c|c|c|c|}
\hline Entry & $\begin{array}{c}\text { Mean } \\
\text { yield } \\
\left(\mathrm{Mg} \mathrm{ha}^{-1}\right)^{\mathrm{z}}\end{array}$ & $\begin{array}{c}\text { Mean } \\
\text { lodging } \\
\text { score } \\
(1-9)^{y}\end{array}$ & $\begin{array}{l}\text { Arch } \\
\text { type }^{x}\end{array}$ & $\begin{array}{c}\text { Mean } \\
\text { days to } \\
\text { maturityw }\end{array}$ & $\begin{array}{c}\text { Mean } \\
\text { common } \\
\text { bacterial } \\
\text { blight } \\
\text { response }(\mathrm{s})\end{array}$ \\
\hline OPB-1 & 2.72 & 6.0 & IIaIII & 104 & $\mathrm{MS} / \mathrm{S}$ \\
\hline OPG-2 & 2.72 & 4.7 & $\mathrm{IIb}$ & 99 & $\mathrm{~S}$ \\
\hline OPB-3 & 3.05 & 4.6 & $\mathrm{IIb} / \mathrm{III}$ & 103 & $\mathrm{MR} / \mathrm{S}$ \\
\hline OPG-4 & 2.92 & 5.2 & $\mathrm{I} / \mathrm{III}$ & 101 & $\mathrm{R} / \mathrm{S}$ \\
\hline OPB-7 & 2.72 & 5.0 & III & 98 & $\mathrm{MR} / \mathrm{S}$ \\
\hline OPG-8 & 2.50 & 4.9 & $\mathrm{IIb} / \mathrm{III}$ & 100 & $\mathrm{R} / \mathrm{S}$ \\
\hline OPG-9 & 3.13 & 5.2 & III & 97 & $\mathrm{~S}$ \\
\hline Jamapa & 2.57 & 3.2 & IIa & 96 & S \\
\hline Dresden & -- & -- & --- & --- & S \\
\hline Xan159 & --- & --- & --- & --- & $\mathrm{R} / \mathrm{MR}$ \\
\hline HR67 & --- & --- & --- & --- & $\mathrm{R}$ \\
\hline PI-440790 & & & & & I \\
\hline $\mathrm{F}_{2.6}-\mathrm{A} \mathrm{K} 2$ & & & & & MS \\
\hline
\end{tabular}

${ }^{\mathrm{z}}$ Yield data were not collected in Ontario. All yield plots were replicated except the Michigan plot of 2003 ANOVA for genotype main effect on yield was not significant at $P=0.05$ level. Mean grouping for alpha $=0.10$.

' Lodging data $(1=$ erect while $9=100 \%$ lodged $)$ were obtained from two trials in Ohio and one in Michigan. ANOVA for genotype main effect on lodging was not significant at $P=0.05$ level.

${ }^{x}$ Architectural type (Type I = determinate, upright growth habit; Type IIa = indeterminate, upright growth habit, short vines; Type IIb = indeterminate, upright growth habit, terminal guide of varying length and climbing ability; Type III = indeterminate, prostrate vining habit) and days to maturity data were not collected in Ohio.

wDays to maturity = days from planning to the time all plants in plot have reached harvest maturity ${ }^{v}$ Common bacterial blight ratings reflect the responses to artificial inoculation observed for each line during 2002 and 2003 seasons in Ontario. I - Immune, $\mathrm{R}=$ resistant, $\mathrm{MR}=$ moderately resistant, $\mathrm{MS}=$ moderately susceptible, and $\mathrm{S}=$ susceptible. Controls were planted only in 2003 season.

cooking time and cooking temperature on hardness and nutritional antagonists. Plant Foods Human Nutr. 36:295-307.

Mejía-Jimenez, A., C. Muñoz, H.J. Jacobsen, W.M. Roca, and S.P. Singh. 1994. Interspecific hybridization between common and tepary beans: increased hybrid embryo growth, fertility, and efficiency of hybridization through recurrent and congruity backcrossing. Theor. Appl. Genet. 1994.88:324-331.
Pratt, R.C. and H.T. Erickson. 1982. Flowering response of Phaseolus acutifolius Gray and sub-species to photoperiod. Annu. Rpt. Bean Impr. Coop. 25:1-2.

Pratt, R.C. 1983. Gene transfer between tepary and common beans, p. 57-63. In: G.P. Nabhan (ed.). The desert tepary as a food resource. A journal symposium. vol. 5. Desert plants.

Pratt, R.C. and S.G. Gordon. 1994. Introgression of Phaseolus acutifolius A. Gray genes into the
Phaseolus vulgaris L. genome. Plant Breeding 113:137-149.

Pratt, R.C. and G.P. Nabhan. 1988. Evolution and diversity of Phaseolus acutifolius Gray genetic resources, p. 409-440. In: P. Gepts (ed.). Genetic resources, domestication, and evolution of Phaseolus Beans. Nijhoff/Junk Publ., Dordrecht, The Netherlands.

Pratt, R.C., R.A. Bressan, and P.M. Hasegawa. 1985. Genotypic diversity enhances the recovery and fertility of $P$. vulgaris L. $\times P$. acutifolius A. Gray hybrids and backcrosses. Euphytica 34:329-344.

Sabja,A.M., D.W.S. Mok, and M.C. Mok. 1990. Seed and embryo growth in pod cultures of Phaseolus vulgaris and $P$. vulgaris $\times P$. acutifolius. HortScience 25:1288.

Scott, M.E. and T.E. Michaels. 1992. Xanthomonas resistance of Phaseolus interspecific cross selections confirmed by field performance. HortScience 27:348-350.

Singh, S.P. 2001. Broadening the genetic base of common bean cultivars: A review. Crop Sci. 41:1659-1675.

Singh, S.P. and C.G. Muñoz. 1999. Resistance to common bacterial blight among Phaseolus species and common bean improvement. Crop Sci. 39:80-89.

Thomas, C.V., R.M. Manshardt, and J.G. Waines. 1983. Teparies as a source of useful traits for improving common beans, p. 51-56. In: G.P. Nabhan (ed.). The desert tepary as a food resource. A journal symposium. vol. 5. Desert plants.

Thomas, C.V. and J.G. Waines. 1984. Fertile backcross and allotetraploid plants from crosses between tepary beans and common beans. J. Hered. 75:93-98.

Urrea, C.A., P.N. Miklas, and J.S. Beaver. 1999. Inheritance of resistance to common bacterial blight in tepary beans. J. Amer. Soc. Hort. Sci. 124:34-27.

Waines, J.G., R.M. Manshardt, and W.C. Wells. 1988. Interspecific hybridization between Phaseolus vulgaris and $P$. acutifolius, p. 485-502. In: P. Gepts (ed.). Genetic resources, domestication, and evolution of Phaseolus beans. Nijhoff/Junk Publ., Dordrecht, The Netherlands.

Table 3. Seed characteristics and cookability of seven diverse Ohio Phaseolus germplasm lines.

\begin{tabular}{|c|c|c|c|c|c|}
\hline \multirow[b]{2}{*}{ Line } & \multirow[b]{2}{*}{$\begin{array}{c}\text { Color } \\
\text { or class }\end{array}$} & \multicolumn{3}{|c|}{ Cookability } & \multirow[b]{2}{*}{$\begin{array}{l}100 \text { Seed } \\
\text { wt }(\mathrm{g})^{\mathrm{w}}\end{array}$} \\
\hline & & $\begin{array}{c}\text { Imbibition } \\
(\% \mathrm{wt})^{\mathrm{z}}\end{array}$ & $\begin{array}{c}\text { Firmness } \\
(\mathrm{g} \text { resistance })^{\mathrm{y}}\end{array}$ & $\begin{array}{c}\text { Visual } \\
\text { quality }^{\mathrm{x}}\end{array}$ & \\
\hline$\overline{\mathrm{OPG}-1}$ & Black (small seed) & 86 & Fully cooked & 1.5 & $20.2 \mathrm{bcd}^{\mathrm{v}}$ \\
\hline OPG-2 & Black (small seed) & 99 & Fully cooked & 1.3 & $18.7 \mathrm{~d}$ \\
\hline OPG-3 & Mixed & 103 & Fully cooked & 1.4 & $23.9 \mathrm{ab}$ \\
\hline OPG-4 & Black, black mottled & --- & --- & 1.4 & $18.4 \mathrm{~cd}$ \\
\hline OPG-7 & Brown mottled & 97 & 197 & 1.0 & $22.6 \mathrm{bc}$ \\
\hline OPG-8 & Brown & 117 & 147 & 1.0 & $27.8 \mathrm{a}$ \\
\hline OPG-9 & Brown mottled & 93 & 159 & --- & $27.8 \mathrm{a}$ \\
\hline Jamapa & Black (small seed) & 97 & Fully cooked & 1.8 & $20.0 \mathrm{bcd}$ \\
\hline Raven & Black (small seed) & 98 & Fully cooked & --- & 18.0 \\
\hline Black Hawk & Black (small seed) & 109 & Fully cooked & --- & 13.4 \\
\hline Commercial Navy & White Navy & 102 & 97 & --- & 26.3 \\
\hline Commercial Black & Black (small seed) & 105 & 195 & --- & 20.7 \\
\hline PI 440790 & White, light green & --- & --- & 1.0 & 13.4 \\
\hline $\mathrm{F}_{2 \cdot 6}-\mathrm{A} \mathrm{K} 2$ & Black & --- & --- & 1.0 & 8.7 \\
\hline
\end{tabular}

${ }^{\mathrm{Z}}$ Imbibtion was performed for 60 min using one sample of 100 seed.

${ }^{\mathrm{y}}$ Firmness (cookability) evaluations were conducted using 15 samples with one seed per sample. Time to cook was determined using a bean cooker described by Jackson and Varianno-Marston (1981). Following $1 \mathrm{~h}$ of cooking, firmness tests were performed with an Instron penetrometer.

${ }^{x}$ Visual evaluations of seed quality on a 1 to 5 scale ( 1 is the best) were made from one plot observed in Ontario during 2003.

w100 seed weight data of OPG lines, Jamapa, and the tepary parents are the mean of values obtained from two locations in Ohio and one in Michigan. Only replicated samples of the OPG lines and the recurrent parent (Jamapa) were tested using Fisher's LSD mean comparisons test. Means within a column followed by the same letter are not significantly different. All other 100 seed weight values were obtained in the cookability study only. 